Abstracta Iranica

Revue bibliographique pour le domaine irano-aryen

Volume 32-33 | 2013

Comptes rendus des publications de 2009-2010

\title{
Touraj Daryaee. When the End is Near: Barbarized Armies and Barracks Kings of Late Antique Iran
}

\section{Rika Gyselen}

\section{(2) OpenEdition}

1 Journals

Édition électronique

URL : http://journals.openedition.org/abstractairanica/40485

DOI : 10.4000/abstractairanica.40485

ISSN : 1961-960X

\section{Éditeur :}

CNRS (UMR 7528 Mondes iraniens et indiens), Éditions de l'IFRI

\section{Édition imprimée}

Date de publication : 1 décembre 2013

ISSN : 0240-8910

\section{Référence électronique}

Rika Gyselen, «Touraj Daryaee. When the End is Near: Barbarized Armies and Barracks Kings of Late Antique Iran », Abstracta Iranica [En ligne], Volume 32-33 | 2013, document 150, mis en ligne le 01 juillet 2016, consulté le 28 septembre 2020. URL : http://journals.openedition.org/abstractairanica/40485 ; DOI : https://doi.org/10.4000/abstractairanica.40485

Ce document a été généré automatiquement le 28 septembre 2020.

Tous droits réservés 


\title{
Touraj Daryaee. When the End is Near: Barbarized Armies and Barracks Kings of Late Antique Iran
}

\author{
Rika Gyselen
}

\section{RÉFÉRENCE}

Touraj Daryaee. « When the End is Near: Barbarized Armies and Barracks Kings of Late Antique Iran ", in : M. Macuch, D. Weber, D. Durkin-Meisterernst, eds., Ancient and Middle Iranian Studies. Proceedings of the 6th European Conference of Iranian Studies, held in Vienna, 18-22 September 2007. Wiesbaden, 2010, p. 43-52.

1 Bien que publié dans les Actes du Congrès de la SIE tenu en septembre 2007, cet article a été fortement stimulé par un ouvrage paru en 2008 dont l'A. suggère qu'une des principales causes de l'incapacité de la dynastie sassanide à repousser les envahisseurs arabes était la rupture du pacte qui avait lié les familles parthes à la famille sassanide. TD propose plusieurs autres raisons pour le déclin rapide de l'empire sassanide comme l'intégration dans l'armée sassanide de contingents étrangers plus fidèles à leurs généraux qu'à la couronne sassanide ('Barbarized armies') et l'impossibilité des successeurs de Khusro II à imposer leur légitimité sur l'ensemble des régions de l'empire ('Barracks kings').

2 Riche en données et parsemé de réflexions profondes et innovantes, cette contribution est un apport majeur pour comprendre les soixante dernières années de l'empire sassanide. 


\section{AUTEURS}

\section{RIKA GYSELEN}

CNRS/Mondes iranien et indien, Paris 